\title{
Collegial Learning and Digital Literacy Education in a Swedish Preschool
}

\author{
Karin Forsling ${ }^{1}[0$ \\ Accepted: 19 November 2021 / Published online: 4 December 2021 \\ (c) The Author(s) 2021
}

\begin{abstract}
This article focuses on preschool teachers' collegial learning in relation to children's use of digital learning tools in preschool. The aim of the study was to investigate how preschool teachers understand, change, and improve learning situations when digital tools are used, under the supervision of a film educator, a preschool colleague, and a researcher. The results show how five dedicated teachers, without a special interest in digital tools, started using tablets in preschool as a learning tool to achieve the goals in the curriculum regarding communication. The experiment model used in the study is based on designoriented theories. The design-based experiment provided an opportunity for in-depth reflection among the teachers and a meeting place for collegial learning processes, which can in turn lead to preschool development.
\end{abstract}

Keywords Collegial learning · Design-based experiments · Design-oriented theory $\cdot$ Digital literacy $\cdot$ Preschool development $\cdot$ Transformation competences

\section{Introduction}

At a time when developing digital literacy is high on the agenda, an interdisciplinary starting-point may provide opportunities for daily activities at preschool. This approach may involve the preschool teachers' own digital literacy, ability to lead activities, integration of digital tools and resources, as well as their approach to using digital tools critically and responsibly. In addition, it involves extended teaching skills. Timperley (2019) argued that collegial learning is extremely valuable for successful practice in preschool. Research shows that personal and professional development walk hand in hand and that development is closely related to how knowledge is put into practice at the preschool, for instance in relation to scaffolding (Hernwall, 2016; Letnes, 2017; Rönnerman, 2013).

Preschool is voluntary in Sweden. Municipalities must offer preschool for children from the age of one. Today, some $80 \%$ of 1 - to 5-year-olds attend preschool in Sweden, if only for a few hours a day. The national curriculum states that education in preschool should lay the foundations for

Karin Forsling

karin.forsling@kau.se

1 Department of Educational Studies, Karlstad University, Universitetsgatan 2, 65188 Karlstad, Sweden life-long learning and be enjoyable and rich in learning for all children (Lpfö18). Preschool should promote the development of children to become active, creative, competent and responsible people and members of society. Children's development and learning take place at all times. Hence, teaching in preschool can be based on content that is planned or appears spontaneously. Preschool teachers are responsible for the educational content of teaching and for promoting development and learning in children. Preschool teachers therefore have a special responsibility in the education provided jointly by the teaching team (Lpfö18).

This article describes and analyses preschool teachers' collegial learning in relation to children's use of digital learning tools in two Swedish preschools in a small municipality in central Sweden. The results show that preschool teachers were willing to test new ways of learning with the children and colleagues with the help of a film educator and using a structured method. The film educator was highly educated in the arts, with specific skills in supervising children and teachers in digital workshops.

Furthermore, the study displayed how different roles and learning by example have an impact on preschool development. 


\section{Aim and Research Question}

The aim of the study was to investigate how preschool teachers understand, change, and improve learning situations when digital tools are used under the supervision of a film educator, a preschool colleague, and a researcher. In particular, the study centres on the following question: how can collegial learning processes help preschool teachers to understand, change, and improve learning environments and situations when digital tools are used?

\section{Overview}

The overview begins with an equality perspective on how and why digital technology was introduced in Swedish preschools, and proceeds with a definition of digital literacy. The overview concludes with collegial learning in a preschool context.

\section{Information Technology for Equality}

IT (information technology) was introduced in the Swedish preschool curriculum for reasons of equality and democracy (Johansson, 2000). Preschools should provide computers in the environment since children's access to them at home might vary. In particular, the use of IT in preschools was justified on the grounds of learning, future work, and democracy. Using IT was expected to lead to variation in and new methods of learning and to change the relationship between child and pedagogue. There would be new possibilities for children with special needs to get further support, and in addition, industry and society expected preschools to prepare children for future work. Democracy includes children's right to equity in education (Brodin \& Renblad, 2015). Nevertheless, when tablets were introduced in Swedish preschools in the early 2010s, there were differences in how these were used between and within preschools depending on pedagogical approach and staff attitudes and competence. The general availability of digital tools and their use among children differ also in terms of gender, socioeconomic background, and other demographic variables (Kjällander \& Riddersporre, 2019).

\section{Digital Literacy}

Digital literacy is one of eight key competences for life-long learning (European Commission, 2019). This competence requires basic IT skills including the ability to retrieve, assess, store, and produce information, and to communicate with and through digital media. It involves creativity and innovation, and also ethical and legal issues. Thomas (2011) emphasized that digital literacy is not restricted to tools but includes our way of thinking critically about the texts that form our world, identity, and culture. International research has tried to identify how technology affects children's cultural constructions and explored issues relating to how and where learning takes place in digital environments (cf. Marsh et al., 2016). Research shows that environments in which pedagogues are unfamiliar with or unmotivated to use digital tools do not encourage children's use either. The role of the pedagogue in relation to the children is an important factor for meaning-making with tablets (Kjällander, 2011). Pedagogues need different types of scaffolding, and their views of children and cultural interplay are important starting-points (Marsh et al., 2016; Enochsson \& Ribeaus, 2020).

\section{Collegial Learning Processes}

In preschool, spontaneous everyday conversations among colleagues are common. When the conversations become more regular, a collegial learning process emerges. Collegial learning is a working method that contributes to the development of teachers' collaboration in a structured way aimed at acquiring knowledge and experience (Hattie, 2012; Owen, 2014; Timperley, 2019). The Swedish Schools Inspectorate (2018) emphasizes collegial learning as a success factor for high-quality preschools. A distinct mark of quality is the exhibition of a learning culture at the preschool, that is, reflective conversations about the goals in the curriculum and a shared ambition to develop the organization. Åsén Nordström (2017) highlighted the importance of a leader to achieve a learning culture through collegial learning. The leader's role is to draw attention to preconceived notions. By doing this, he or she makes the participants in a conversation aware of possible ways to change their ways of thinking and working in the team (Åsén Nordström, 2017). While the concept of collegial learning is seldom clearly defined, it can be problematized. Collegial learning often refers to individual learning that takes place with some help from colleagues. However, to reach the aims of organizational development it is important that employees not only learn from each other but also create mutual understanding and draw mutual conclusions (Larsson, 2018).

\section{Design-Oriented Theory}

The study is based on design-oriented theory, which rests on social theories such as social semiotics and multimodality (Kress \& van Leeuwen, 2001). Design theory derives from issues of how new conditions of communication in an increasingly digitalized world affect knowledge and learning 
(cf. Jewitt, 2012). A design-oriented perspective on learning provides an opportunity to explore the learning process and find out how we actually learn something.

Didactic design, or designs for learning, can simply be described as the design of teaching and learning processes. Didactic design includes several agents with different roles; in preschool, for instance, both pedagogues and children can be designers. The pedagogue is an agent who actively chooses the system of signs to be used in designs for learning. The choice of method and tool determines whether the action is considered meaningful or not (Selander \& Kress, 2010).

The issue of meaning-making is connected to teachers' ability to take a flexible approach to teaching, the resources they use in different situations, how they shape social processes to make affordances for learning, and how they design and redesign information in their own meaning-creating processes (Elm Fristorp, 2012). Didactic flexibility can be termed transformation competence-in the sense of the ability to use different learning tools on different learning occasions and at different stages (see Forsling, 2017, 2021). Transformation includes the sum of events, changes and actions that provide a readiness for the challenges that may arise. Transformation competence includes didactic flexibility involving personal differences as well as differences between various learning tools (see Forsling, 2017; Rose \& Meyer, 2002).

Lund and Hauge (2011) point to the importance of highlighting collective activity and actors' intentions. Didactic design can thus be defined and understood as a social practice prioritising agency and dynamics instead of content, methods, and objects. These practices must include continual opportunities for all participants to reflect upon, to design, to stage, and to evaluate teaching.

\section{Methods}

In terms of method, the study draws on design-based research (DBR). DBR is a methodology designed by and for educators that seeks to increase the impact, transfer, and translation of education research into improved practice (Anderson \& Shattuck, 2012, p 16). Design-based research methods enable the study of complex systems, involving known and unknown factors interacting between several variables previously hidden from the researcher (Brown, 1992; Collins, 1992). According to Collins (1992), DBR focuses on design and testing of significant interventions. The intervention is a collaborative task of both researchers and practitioners, designed specifically to overcome some problem or create an improvement in local practice. Furthermore, Anderson and Shattuck (2012) state that DBR interventions are seldom, if ever, designed and implemented perfectly. There is always room for improvement and development.

DBR is a research method that bridges the gap between theory and practice. Teachers get theoretical tools to understand and develop their practice. The teachers' proven experience and tacit knowledge complement the theory, connecting it directly to the educational activities without reducing their complexity (Anderson \& Shattuck, 2012). The result of the study is not generalizable but transferable. Similar studies could be conducted in preschools all over the globe.

\section{Design-Based Experiment as a Method for Investigation}

With DBR as a methodological base, this study used a design-based experiment (DBE) method as the method of investigation. The experimental aspect lies in the researchers' and the pedagogues' receptivity to the unexpected and their flexibility and transformation competence. The method of investigation specifically involved the staff in two preschools, the researcher, and co-researchers jointly designed teaching situations with digital tools. The design and setting changed and were reconfigured as the study progressed, for instance due to organizational, pedagogical, and/or personal reasons.

Design-based experiment research means that the experimental construction, that is, the experimental design, always undergoes changes and modifications during the course of study. The change of implementation can also change the road to attaining the aim of a study, or generate data that the original design made impossible (Bannan-Ritland et al., 2008).

\section{Selection, Information, and Consent}

Two preschools, Sunflower and Ladybug, situated in a small Swedish town, participated in the study. One of the pedagogues, Mia, was selected as a co-researcher as she had shown interest in school development and research on digital tools in preschool. The municipality employed the film educator. In total four pedagogues, two from each preschool, and 25 children aged four to five participated. Parents were contacted and after receiving oral and written information about the study and its purpose, they gave written consent to their children taking part. The co-researching pedagogue Mia was employed as a pedagogue at Ladybug and had the equivalent of one day a week for the study. Mia participated in audio recordings, film and photo sessions, and transcriptions. Mia's initial role at Ladybug was to lead the sessions with the children and model a structure for her colleagues. 


\section{Data Collection}

Data collection was made through observations, interviews and reflective conversations in the two research tracks, documented by field notes, photos, and audio-visual recordings. A mobile phone without internet connection and a digital camera were used for audio-visual recordings of events and conversations. Data material was saved on an external hard drive.

\section{Analysis}

The analysis of the collected material was made through qualitative thematic content analysis, that is, categorization of meaning (Ryan \& Bernard, 2003). Data were coded and grouped in themes, such as collegial interaction, educational challenges, technological challenges, and the power of reflection. In the following part of the analysis, these themes and related theoretical concepts were used and linked to the data material (see Loseke, 2013). The key concepts were derived from design theory: flexibility and collective activity (Elm Fristorp, 2012; Jewitt, 2012; Kress, 2009; Leijon \& Lindstrand, 2012; Lund \& Hauge, 2011; Selander \& Kress, 2010). Flexibility appeared in the material when the actors used different resources in different situations, and influenced how they created the conditions for learning. Collective activity was made visible when the actors shaped social prerequisites, and in the meaning-making processes, when the learning situations were designed and re-designed. The two parts of the analysis were concluded when the central themes of the empirical study were tied together in a descriptive statement (see Denscombe, 2009), as depicted in the resulting themes.

\section{Ethical Reflections}

The pedagogues and the parents were informed about the purpose of the study and its design. They submitted consent forms and were informed that they could withdraw at any time without giving a reason. During the data collection, the children were interested and favorably disposed to our presence and to being filmed. It is, however, important to consider the ethical aspects of children participating in a study. Even if the guardians have given their consent, we were still very observant of any signals of children being uncomfortable during the filming.

\section{Results and Analysis}

During the observations in track 1 at preschool Sunflower, where the film educator Eva conducted the sessions, Mia and I recorded the activities with one camera each. I then selected sequences from the film that were used in the next step for discussions with the staff and reflections for the next session. The reflection opportunities were scheduled between 1 to 8 days later, depending on logistics. This procedure was repeated on seven occasions-a total of fourteen meetings. In addition to these occasions, the start-up and feedback sessions with the pedagogues Mimmi and Helena were documented. During the reflection rounds, Mia took notes, which were transcribed.

During the observations in track 2 at preschool Ladybug, where Mia conducted the sessions, a staff member or I made the video recordings. Directly after the session, Mia, the staff member, and me jointly selected material for discussion and reflection. This procedure was repeated on six occasions. In addition to these occasions, the start-up and feedback sessions with the pedagogues Kajsa, Ulla, and Mia were documented. Mia and her colleagues took turns taking notes in the reflection sessions. The notes were used for documentation and as a basis for the discussions in the group of pedagogues. I took photos and notes, or recorded conversations in reflection sessions. Data material was transcribed by the co-researching pedagogue and researchers, and compiled into a readable text.

\section{Results}

The results present, in a descriptive mode, two photo sessions and two reflection rounds, at Sunflower and Ladybug respectively. The selection of these sections is based on two considerations. First, the main reason is their relevance for the aim of the study. Second, they are adequate for the reader's understanding of what an investigation situation might look like. In the descriptions, the themes flexibility and collective activity are present and visible, but to keep the narrative mode in this first part, the analysis is dealt with at the end of this chapter.

\section{Sunflower: 'I Didn't Think I'd Said that but I Had"}

On this occasion the film educator, Eva, was not present and the pedagogues had designed the session themselves and planned the reflection round directly after the session. The following learning outcomes were chosen for the activity with tablets:

Preschools should strive to make every child take an interest in images, texts, and different media and to use their ability to interpret and talk about them. (Lpfö 98, rev. 2016) 


\section{Photo Session Sunflower}

The children were sitting on a round blue mat in their group room together with Mimmi and Helena. Mimmi introduced the task with enthusiasm that the children were given in a letter -to take photos of anything beginning with the letter D. Helena took her group and moved to another activity in an adjacent room. After half the session, Helena returned with her group and Mimmi took her group to the adjacent room. Both groups of children showed great interest and focus during the photo session. They walked, discussed, and took photos. Some children looked to the pedagogue for support, and occasionally the pedagogue gave a little support to a child. Some children took a long time to get the picture they wanted and others returned to the mat, satisfied with their pictures. During the exhibition (presentation on the mat), the children took turns to describe what their photo showed and where it was taken. The other children and the pedagogue asked follow-up questions. When the sessions were completed, the children mixed again, some went to another unit, and some went home.

\section{Reflection Round Sunflower}

Mimmi said that she had wanted to give a child more time. Both Helena and Mimmi reflected on their newly acquired confidence in relation to daring to relinquish control and letting the children do something on their own.

We watched the video sequences from Helena's session. Helena commented that three children seemed to think alike, while a fourth child took his own route. Helena noted the child that needed more time. She emphasized that he needed more guidance. Mimmi and Helena discussed how the children and Helena acted in the sequences. Helena remarked that she saw things she had not noticed in the session:

I can see that in the film now, but I didn't notice it at the time. He is reasoning a lot with himself and is talking and $\mathrm{M}$ joins him in his thinking a bit. His way of processing and discussing with himself and the friend next to him...

We continued with sequences of Mimmi's session. Helena noted the differences between the children and observed that it was easy to misunderstand events. The pedagogues discussed the girl who seemed unfocused during the session but who, captured on film, appears to study her hands with great concentration once she has discovered them in the tablet camera. Mimmi also noted that she confirmed the children and their questions, thus helping them to be more confident in their task.
Mimmi and Helena produced post-it notes with their reflections. Mimmi argued that the children were given an opportunity to challenge themselves and to present, interpret, and talk about the pictures, texts, and letters together. Helena pointed out that the children explained their thinking about their picture and that they had reflected on their friends pictures:

It's not only how they think themselves but how they reached the ability to discuss a picture, also the friend's picture. They can formulate how they think. They started a discussion.

\section{Ladybug: 'The Method Creates Good Conditions"}

The pedagogues had planned a child-initiated theme, 'Water', and they had decided on the following learning outcomes for the digital work with the tablets:

Preschools should ensure that each child develops their ability to listen, reflect and express their own perceptions and to try to understand others' perspectives (Lpfö 98, rev. 2016).

\section{Photo Session Ladybug}

Kajsa and Mia were sitting on the round mat in the playroom with three 4-year olds, Julia, Emma and Ami. Kajsa conducted the session, and placed three tablets on the mat. Mia was sitting next to Ami as extra support with language and focus, while I was filming.

Kajsa started by referring back to what they had talked about in the previous session. She recounted the children's suggestions about what we can do with water: have a bath, wash, do the dishes, and reminded them about words for how it can feel: warm, cold. The children talked about how water can burn you and that it can become a block of ice when it is cold. A child told us about a balloon which froze and then thawed. They continued to discuss the properties of water for a while.

Kajsa gave the children their first task: take three photos of water. The children went off to take photos. When they returned, Emma and Julia talked about the colors of water. At the exhibition, they looked at each other's pictures and talked about them.

Kajsa asked the children to take three new photos of water. Julia and Emma went on towards the water tap in the painting room, where they took a variety of water photos. They experimented by placing colored bottles behind the tap water stream. A child photographed a lake on a mat. Ami went to the toilet, pointing to the seat. At the exhibition, the children and the pedagogues discussed what water could look like. Ami tried to describe her picture. The other children waited for her to speak. She looked at Emma's photo and said, a bit inaudibly, "water". 
Kajsa and Mia joined me in the playroom to watch the video. I showed them the sequences and stopped when the pedagogues or I wanted to comment on something.

\section{Reflection Round Ladybug}

Mia pointed out that the feedback from the previous session was important because the conversation on the mat went deeper, and the children talked more.

Kajsa noted that the pedagogues were more active and more used to the situation. They discussed the challenge of getting Ami to talk about her photo. Mia thought that Ami had an "aha" moment when she saw Emma's photo, pointing at it and saying "water". They reflected on the fact that during the sessions Ami had been given more difficult tasks than specified in her development plan and still managed.

In the discussion on how learning outcomes had been be reached in the session, the pedagogues mentioned exploration, deeper knowledge, respect, reciprocity, and safety. Mia concluded:

The feedback was good for Ami - able to express herself. We have created a situation where she can practise. The others waited for her. The method creates good conditions.

Mia took notes during the reflection, which were put into a folder and shared with the other pedagogues some days later, and also used as a basis for the pedagogues conducting the next session.

\section{Analysis-Flexibility}

The pedagogues assumed active roles as designers in the specific institutional environment studied. This form of agency was intimately linked to flexibility and collegial learning.

\section{Didactic Flexibility}

In the analysis, it turned out that the resources the pedagogues used in different situations were important, but even more important was how they formed social processes and created conditions for learning.

Digital tools were seldom used in daily preschool activities earlier. Kajsa, at the preschool Ladybug, was interested in digital technology and often took photos for her own use. Another pedagogue at the same preschool, Ulla, was completely without interest in digital tools and used very little technology in her personal or professional life. Only Mia had an idea about the use of digital tools for learning in preschools.

The pedagogues were of the opinion that they had undergone professional development during the study. This involved handling tablets, and understanding their usefulness as pedagogical tools. New insights related to transparency and structure, which gave confidence as well as freedom to explore and develop. They talked about taking an interest in children's thoughts and reflections.

We caught the children's interest: what will happen?

The tasks were important. Important to show each other. What did you think here? That children understand that they have understood something in a different way from their friend. Good training waiting for their turn. (Ulla)

The pedagogues pointed out that the new insights surprised them-why had not they thought like this before? The important question: What did you think here? was put more often to both children and adults.

When the pedagogues discussed preschool goals, they emphasized teaching and guiding and creating wonder.'It is important to guide, control, and challenge", one of the pedagogues said."We have been exploring," said another. Being conscious and confident in the learning situation were qualities often mentioned in the interviews.

\section{Changes in the Learning Environment}

No major changes were made in the physical learning environment at Sunflower. Helena and Mimmi were worried that the inadequate allocation of resources could jeopardize further development of digital literacy for children as well as adults. Spontaneous work was prevented.

However, the cultural and educational environment had improved, as the pedagogues testified to being inspired and having new ideas and said that they wanted to continue using tablets in the preschool:

Based on the tasks we have given, I feel more comfortable in conveying to them what they should do. New ideas and how develop them further. And how to use this [tablet] as a tool. (Helena)

At Ladybug, great changes were made in the cultural and educational learning environment. It was clear in the course of the project that the pedagogues had adopted a new approach:

We are in the process of developing our own reflection rounds based on the children's pictures and thoughts. We have really implemented it. (Mia) 
The children take pictures in a different way. They shoot events, movements and phenomena. They ask adults to take photos and video record. The children understand the purpose and value. The camera has become a natural tool. (Mia)

\section{Analysis-Collective Activity}

Collective activity was particularly conspicuous during observations and reflection rounds, and also in the analysis of the pedagogues' discussions of children's development and how their joint work should advance the teaching and learning process. From a design-oriented perspective, learning is seen as a social practice based on collective activity and actors' intentions (Kress \& van Leeuwen, 2001; Lund \& Hauge, 2011). The pedagogues' aims for their design were related to the learning outcomes-the ambition that all children should develop an ability to listen, reflect, and express their perceptions while trying to understand others' perspectives, and that all children should develop an interest in images, texts, and different media as well as the ability to use, interpret, and discuss them. In the analysis, the pedagogues' discovery of the interplay in the learning processes among children and between children and adults is displayed.

\section{Role of Reflection Rounds}

Collegial processes of learning took place during the reflection rounds at the preschools. In turn, this affected confidence, approaches, and concrete work in the team and in the groups of children. Self-reflection and reflection on the actions of colleagues in the video sequences created a greater sense of agreement in the team. The pedagogues talked about benefitting from each other's competences and the importance of being present as pedagogues.

We complement each other, pool our knowledge, get to know each other's approaches and view of children. We know how our colleagues think in different situations and then it's easy to support and push each other. Thanks to the reflections learning is good. (Kajsa)

The pedagogues at Ladybug started to video record each other and themselves to study and reflect on their actions in different learning situations. They described reflection rounds as the basis for development in a safe and sound environment. A pedagogue talked about how reflection opportunities had been an asset in team development and how they had been challenged and forced to express their thoughts and actions in words.
We clearly see what the children do from their perspective, how we can build on that the next time. How we should think. It is also the way this creates consensus and a sense of safety in the team. (Mia)

\section{Children's Development in Relation to the Learning Outcomes}

Learning took place in cooperation between children and pedagogues. The children learned, often from each other, the technique of finding the right functions for the camera and video and for the pictures they wanted to work with. They discovered that the tablet was more than a game device. They used the tablets to take photos, make selections, compare, describe, listen, discuss, and to respect speech turns and turn-taking. The sense of security that was established in the sessions gave the children the courage to talk about their thoughts in social interaction. Their talk about the pictures increased during the study and there was open communication with no right or wrong statements. The child perspective was highlighted.

We experience that there is more exploring and we are curious about what the children are thinking. (Mia) The children's pictures have made children as well as adults reflect. We express in words what we think/do and the children's abilities have become manifest to us. (Mia)

\section{Discussion}

The aim of the study was to investigate how preschool pedagogues can understand, change, and improve learning environments and learning situations where digital tools are used. The pedagogues in the study designed activities in which children used tablets to take photos. The children were given different tasks and together with the pedagogues, they discussed the pictures that they themselves had selected for an exhibition. In this way, the young photographers became explorers in their own context as they were given the opportunity to talk about the photos and their environment with the pedagogues. An important aspect was that the children, in this way, were no longer only consumers of media but at an early age invited to produce their own media content, which may be important for an early and conscious digital literacy (cf. Kjällander, 2011).

My role as a researcher was to document sequences of learning in practice, not for the sake of displaying learning per se, but sequences demonstrating the process of learning. Discovering and reflecting on learning was the task of the pedagogues. The experimental community was central 
and I acted as a sounding board without reducing the pedagogues' agency. As a design-based researcher, my purpose was to draw attention to preconceived notions in order to let the participants in the conversation become aware of how their way of thinking and working in the team could change (cf. Åsén Nordström, 2017). It is however possible that an internal actor - the co-researcher Mia—was the most important factor in relation to the aim that preschool pedagogues should get tools to understand, change, and improve learning environments and situations where digital tools are used.

\section{Flexibility for Meaning-Making}

The meaning-making offered to children in a digital learning environment is influenced by the pedagogues' approach to digital tools and their use (Elm Fristorp, 2012). The pedagogues showed ability to make digital learning situations meaningful for the children but they also noted that the insufficient allocation of digital tools made creative teaching more difficult, which also Kjällander (2011) has noted in research on and mapping of Swedish preschools. From a design theoretical perspective, everybody is seen as an agent in preschool practice, adults and children alike. Research shows that personal and professional development is closely related to how knowledge is used in practice and if there are support structures in the organization (Forsling, 2021; Letnes, 2017; Rönnerman, 2013). In order to provide a creative digital practice in harmony with preschool learning outcomes, the pedagogues developed their transformation competence, which comprises the extended pedagogical and didactic skill of being able to answer the more difficult and complex question of why we teach, rather than what and how we teach.

This study clearly shows the importance of internal as well as external agents in development work. Initially it involves individuals who want to and can make a difference. Film educators and researchers can serve as external actors for a development project. The pedagogues described how a person with more knowledge could support their learning. The importance of collective learning for successful preschool activities is emphasized by Timperley (2019), who points out that collegial professional development affects teachers as well as children.

\section{Collective Activities for Collegial Learning}

The use of digital tools affected the interaction between individuals and between individuals and artefacts. The pedagogues learned from each other and were inspired by modelling, good examples, reflecting together and on their own, and children's learning processes. Didactic design is a social practice, a collective activity with priority given to agency and flexibility, and this was manifested in the study.
There were opportunities for the participants to evaluate and continuously reflect, which also Thomas (2011) emphasizes as important factors in digital literacy.

The pedagogues' reflections on their teaching practice are prominent in the study. The pedagogues remarked on their discovery of their own professionalism and the importance of using similar models on their own to advance preschool activities. However, there are not only reflections on practice-there are also reflections in practice, reflections that emanate new ways of thinking and acting. This is adjacent to the notion of collegial learning as a collective creation of mutual understanding and mutual conclusions (Larsson, 2018).

\section{Understanding, Changing, and Improving Learning Environments and Situations}

Success factors for providing digital literacy to children in preschool are the teachers' competence and ability to lead activities, integrate digital tools and resources in teaching, and give children clear and attainable challenges. This further requires that preschool teachers and other staff are familiar with the use of digital tools. This study shows how five committed pedagogues with no particular digital habits or interest in digital tools used tablets in preschool as a teaching tool to reach curricular goals relating to communication. Modelling by the film educator added structure and practical exercises and the reflection rounds in connection with exercises provided conditions for collegial learning, which resulted in understanding and explorative development of possible digital practices in the preschools. The pedagogues emphasized direction, teaching, guiding and also creating wonders and posing challenges in their discussions of preschool curriculum goals, revealing their understanding of and confidence in the new learning situation. A meeting-place for collegial learning emerged in the intersection between sessions, reflection rounds, and staff discussions.

The tablet sessions were organized according to a certain structure but in an attractive and playful way. Through the discussions of the pictures in the sessions, the pedagogues pointed to the children's engagement, and in the subsequent reflections, the pedagogues could jointly discover how children think. The pedagogues discovered how the world of children could be discovered based on a single photo. The stories around the photo lent a voice to the children, which the staff might not have discovered otherwise. The encounter between the children's perspective and the pedagogues' understanding produced new knowledge and the pedagogues' views of the children and cultural interplay became important. The encounter was context-creating as well as meaningful in the sense of "full of meaning". 


\section{Design Experiment Bridges the Gap between Theory and Practice}

Based on the didactic design perspective, the formative processes in which children and adults were involved in the study were foregrounded. Through the design of the study, the pedagogues had access to theoretical tools to understand and develop their practice. The fact that the participating teachers in a design experiment to a great extent are subjects in a research process means that their proven experience and tacit knowledge complement the theory. The theory is thus based in and linked directly to teaching practice and its complexity. Exploring their own practice led to further development of professional understanding as well as an increased ability to change and improve environments and situations of learning in preschools. There is a clear movement forward, towards continued progress.

\section{Author Contributions Not applicable.}

Funding Open access funding provided by Karlstad University. Not applicable.

Data Availability Not applicable.

Code Availability Not applicable.

\section{Declarations}

Conflict of interest The authors declare that they have no conflict of interest.

Open Access This article is licensed under a Creative Commons Attribution 4.0 International License, which permits use, sharing, adaptation, distribution and reproduction in any medium or format, as long as you give appropriate credit to the original author(s) and the source, provide a link to the Creative Commons licence, and indicate if changes were made. The images or other third party material in this article are included in the article's Creative Commons licence, unless indicated otherwise in a credit line to the material. If material is not included in the article's Creative Commons licence and your intended use is not permitted by statutory regulation or exceeds the permitted use, you will need to obtain permission directly from the copyright holder. To view a copy of this licence, visit http://creativecommons.org/licenses/by/4.0/.

\section{References}

Anderson, T., \& Shattuck, J. (2012). Designbaserad forskning: Ett decennium av framsteg inom utbildningsforskning? [Designbased research. A decade of progress in educational research?]. Educational Researcher, 41(1), 16-25.

Åsén Nordström, E. (2017). Kollegialt lärande genom pedagogisk handledning och lärande samtal [Collegial learning through pedagogical guidance and learning conversations]. Liber.
Bannan-Ritland, B., Gorard, S., Middleton, J., \& Taylor, C. M. (2008). The "compleat" design experiment: From soup to nuts. In A. E. Kelly, R. A. Lesh, \& J. Y. Baek (Eds.), Handbook of design research methods in education: Innovations in science, technology, engineering, and mathematics learning and teaching (pp. 21-46). Routledge.

Brodin, J., \& Renblad, K. (2015). Early childhood educators' perspectives of the Swedish national curriculum for preschool and quality work. Early Childhood Education Journal, 43(5), 347-355.

Brown, A. L. (1992). Design experiments: Theoretical and methodological challenges in creating complex interventions in classroom settings. The Journal of the Learning Sciences, 2(2), 141-178.

Collins, A. (1992). Toward a design science of education. In E. Scanlon \& T. O'Shea (Eds.), New directions in educational technology (Vol. 96, pp. 15-22). Springer.

Denscombe, M. (2009). Forskningshandboken: För småskaliga forskningsprojekt inom samhällsvetenskaperna [Research handbook: For small scale research projects in social sciences]. Studentlitteratur.

Elm Fristorp, A. (2012). Design för lärande : Barns meningsskapande i naturvetenskap [Design for Learning : Children's Meaning-making in Science]. Dissertation, Stockholms universitet.

Enochsson, A.-B., \& Ribeaus, K. (2020). Everybody has to get a chance to learn: Democratic aspects of digitalisation in preschool. Early Childhood Education Journal. https://doi.org/10.1007/ s10643-020-01117-6

European Commission. (2019). Key competencies for lifelong learning. Retrieved from https://ec.europa.eu/education/policies/school/ keycompetences-and-basic-skills_en.

Forsling, K. (2017). Att överbrygga klyftor $i$ ett digitalt lärandelandskap. Design och iscensättning för skriv-och läslärande i förskoleklass och lågstadium [Bridging gaps in a digital learning landscape. Design and setting for writing and reading education in preschool class and primary school]. Dissertation, Ảbo Akademi.

Forsling, K. (2021). Children's Cultural Backpack and Preschool Education: A Design-Based Study in a Swedish Preschool In: L. Haas, \& J. Tussey (Eds.), Connecting disciplinary literacy and digital storytelling in K-12 education (pp. 169-191). IGI Global Advances in Early Childhood and K-12 Education (AECKE) Book Series. https://doi.org/10.4018/978-1-7998-5770-9.ch009

Hernwall, P. (2016). 'We have to be professional'—Swedish preschool teachers' conceptualisation of digital media. Nordic Journal of Digital Literacy, 11(1), 5-23.

Hattie, J. (2012). Synligt lärande för lärare [Visible learning for teachers]. Natur \& Kultur.

Jewitt, C. (2012). Technology, literacy and learning: A multimodal approach. Routledge.

Johansson, A.-C. (2000). Multimedia i förskola och skola. [Multimedia in preschool and school]. Ekelunds förlag $\mathrm{AB}$.

Kjällander, S. (2011). Designs for learning in an extended digital environment: Case studies of social interaction in the social science classroom. Dissertation. Stockholms universitet.

Kjällander, S., \& Riddersporre, B. (2019). Digitalisering i förskolan: på vetenskaplig grund. [Digitalisation in Preschool: On a scientific basis]. Natur \& Kultur.

Kress, G. (2009). What is mode? In C. Jewitt (Ed.), The Routledge handbook of multimodal analysis. Routledge.

Kress, G., \& van Leeuwen, T. (2001). Multimodal discourse: The modes and media of contemporary communication. Arnold.

Larsson, P. (2018). Kollegialt lärande och konsten att navigera bland begrepp [collegial learning and the art of navigating through concepts]. In N. Rönnström \& O. Johansson (Eds.), Att leda skolor med stöd i forskning-exempel, analyser och utmaningar. Natur och kultur.

Leijon, M., \& Lindstrand, F. (2012). Socialsemiotik och design för lärande: Två multimodala teorier om lärande, representation och 
teckenskapande [Sociosemiotics and design for learning: Two multimodal theories about learning, representation and sign production]. Pedagogisk Forskning i Sverige, 17(3-4), 171-192.

Letnes, M. A. (2017). Legende Laring med Digitale Medier [Playful Learning with Digital Media], Akademisk Forlag.

Loseke, D. R. (2013). Methodological thinking: Basic principles of social research design. Sage Publications Inc.

Lpfö18, Läroplan för förskolan. [Curriculum for the preschool]. Skolverket.

Lpfö 98, rev. 2016. Läroplan för förskolan. [Curriculum for the preschool]. Skolverket.

Lund, A., \& Hauge, T. E. (2011). Designs for teaching and learning in technology-rich learning environments. Nordic Journal of Digital Literacy, 6(4), 258-271.

Marsh, J., Plowman, L., Yamada-Rice, D., Bishop, J., \& Scott, F. (2016). Digital play: A new classification. Early Years: An International Journal of Research and Development, 36(3), 242-253.

Owen, S. (2014). Teacher professional learning communities: Going beyond contrived collegiality toward challenging debate and collegial learning and professional growth. Australian Journal of Adult Learning, 54(2), 54-77.

Rose, D.H., \& Meyer, A. (2002). Teaching every student in the digital age: Universal design for learning. Association for Supervision and Curriculum Development, Alexandria
Ryan, G. W., \& Bernard, H. R. (2003). Techniques to identify themes. Field Methods, 15(1), 85-109.

Rönnerman, K. (2013). Kvalitetsarbete i förskolan belyst genom tre ledningsnivåer [Quality work in preschool highlighted through three levels of management]. Pedagogisk Forskning i Sverige, 18(3-4), 175-196.

Selander, S., \& Kress, G. (2010). Design för lärande: Ett multimodalt perspektiv. [Designs for learning: A multimodal perspective]. Norstedts Akademiska Förlag.

Swedish Schools Inspectorate. (2018). Förskolors värdegrundsarbete [Work with values in preschools]. The Swedish Schools Inspectorate.

Thomas, A. (2011). Towards a transformative digital literacies pedagogy. Nordic Journal of Digital Literacy, 6(1-2), 89-102.

Timperley, H. (2019). Det professionella lärandets inneboende kraft [The inner force of professional learning]. Studentlitteratur.

Publisher's Note Springer Nature remains neutral with regard to jurisdictional claims in published maps and institutional affiliations. 